\title{
PERLINDUNGAN HUKUM TERHADAP PEMBELI LELANG DALAM PELAKSANAAN LELANG EKSEKUSI HAK TANGGUNGAN
}

\author{
Dea Mahara Saputri \\ Universitas Pamulang \\ dosen02432@unpam.ac.id
}

\begin{abstract}
Mortgage Rights arises because of an agreement, namely an agreement between the parties. Legal protection for auction winners means legal certainty of the rights of the buyer / auction winner for the objects bought through the auction. In the auction process that has been carried out in practice, it will cause legal consequences, namely the transfer of auction object rights from the seller to the buyer / winner of the auction as stipulated in Law No. 4 of 1996 concerning Mortgage Rights and Objects Related to Land. In transferring the rights of the auction object, it is not uncommon to cause a problem, such as the object of the auction cannot be controlled by the buyer / auction winner, in which the owner of the auction object does not want to voluntarily vacate the auction object.
\end{abstract}

Keywords: Legal Protection, Auction Buyer, Auction, Mortgage Rights.

\begin{abstract}
ABSTRAK
Hak Tanggungan timbul karena adanya suatu perjanjian, yakni adanya kesepakatan antara para pihak. Perlindungan hukum terhadap pemenang lelang berarti adanya kepastian hukum atas hak pembeli/pemenang lelang atas obyek yang dibelinya melalui lelang. Dalam proses lelang yang telah dilakukan pada praktiknya akan menimbulkan akibat hukum yaitu peralihan hak obyek lelang dari penjual kepada pembeli/pemenang lelang sebagaimana telah diatur dalam Undang-Undang No. 4 Tahun 1996 Tentang Hak Tanggungan Atas Tanah Beserta Benda-Benda Yang Berkaitan Dengan Tanah. Dalam peralihan hak obyek lelang tersebut ternyata tak jarang menimbulkan suatu permasalahan, seperti tidak dapat dikuasainya obyek lelang oleh pembeli/pemenang lelang, yang mana pemilik objek lelang tidak mau dengan sukarela untuk mengosongkan objek lelang tersebut.
\end{abstract}

Kata Kunci : Perlindungan Hukum, Pembeli Lelang, Lelang, Hak Tanggungan. 


\section{PENDAHULUAN}

Dalam perjanjian kredit terdapat dua perjanjian yakni perjanjian pokok dan perjanjian tambahan (accesoir). Perjanjian pokoknya merupakan perjanjian kredit yang dibuat bank bersama debitur dalam rangka kegiatan usaha pemberian kredit perbankan, dan perjanjian accesoirnya merupakan perjanjian hak tanggungan. Dibuatnya suatu perjanjian kredit antara bank dengan debitur bertujuan agar memberikan kepastian atas pengembalian pinjaman. Perjanjian pinjam meminjam antara bank dengan peminjam diikat dengan hak jaminan.

Di dalam suatu perjanjian kredit menghendaki adanya jaminan atau agunan yang dapat digunakan sebagai pengganti pelunasan hutang bilamana dikemudian hari apabila debitur cidera janji atau wanprestasi. Dalam perjanjian kredit terdapat hak dan kewajiban masingmasing pihak, termasuk jangka waktu serta bunga yang ditetapkan bersama. Demikian pula dengan masalah sanksi apabila debitur wanprestasi terhadap perjanjian kredit yang telah dibuat bersama. Jika terjadi kredit macet, maka langkah yang dilakukan untuk penyelamatan kredit tersebut beragam.

Dikatakan beragam karena dilihat terlebih dahulu penyebabnya. Jika memang masih bisa dibantu, maka tindakan membantu apakah dengan menambah jumlah kredit atau dengan memperpanjang jangka waktunya. Namun apabila sudah tidak dapat diselamatkan kembali, maka tindakan terakhir bagi Bank adalah menyita jaminan yang telah dijaminkan oleh nasabah dalam hal ini berupa tanah dan atau bangunan yang telah dijaminkan dengan Hak Tanggungan. Dalam hal demikian, apabila telah melewati proses somasi atas perjanjian utang-piutang dalam hak tanggungan, tetapi masih tidak dapat memenuhi prestasinya maka sertifikat hak tanggungan memiliki nilai kekuatan eksekutorial. Berdasarkan ketentuan Pasal 6 Undang-Undang Nomor 4 Tahun 1996 tentang Hak Tanggungan yaitu: "Apabila debitur cidera janji, pemegang Hak Tanggungan pertama mempunyai hak untuk menjual obyek Hak Tanggungan atas kekuasaan sendiri melalui pelelangan umum serta mengambil pelunasan piutangnya dari hasil penjualan asset tersebut", artinya adalah apabila debitur cidera janji, pemegang Hak Tanggungan pertama mempunyai hak untuk menjual objek Hak Tanggungan atas kekuasaan sendiri melalui pelelangan umum serta mengambil pelunasan piutangnya dari hasil penjualan tersebut. Konsep ini dalam KUHPerdata dikenal sebagai Parate Eksekusi sebagaimana dimaksud dalam Pasal 1178 ayat (2) KUHPerdata.

"Dengan konsep parate eksekusi, pemegang Hak Tanggungan tidak perlu meminta persetujuan terlebih dahulu kepada pemberi Hak Tanggungan, dan tidak perlu juga meminta penetapan pengadilan setempat apabila akan melakukan eksekusi atas Hak Tanggungan yang menjadi jaminan utang debitur dalam hal debitur cidera janji. Pemegang Hak Tanggungan dapat langsung datang dan meminta kepada Kepala Kantor Lelang untuk melakukan pelelangan atas objek Hak Tanggungan yang bersangkutan. (Remy Sjahdeini, 1999 ;46). Lelang dikenal sebagai suatu perjanjian yang termasuk jual beli. Herodotus menuis bahwa lelang mulai ada pada tahun 500 SM di Babylon (Vijay Krisna, 2002 ; 1). Sebagaimana kita ketahui bahwa lelang termasuk dalam perjanjian bernama (nominaat) atau perjanjian khusus (benoemd), karena mempunyai nama sendiri "lelang". Peralihan hak melalui lelang dapat dibagi menjadi dua bentuk, yaitu peralihan hak dengan beralih dan peralihan hak dengan cara dialihkan" (Urip Santoso, 2010 ; 383).

Lelang sendiri mengandung unsurunsur yang tercantum dalam definisi jual beli adanya subjek hukum, yaitu penjual 
dan pembeli, adanya kesepakatan antara penjual dan pembeli tentang barang dan harga, adanya hak dan kewajiban yang timbul antara pihak penjual dan pembeli. Lelang adalah jual beli dalam bentuk khusus (Bachtiar Sibarani, 2006 ; 4). Di samping itu, lelang harus dilaksanakan dihadapan Pejabat Lelang. Jual beli lelang harus didahului penawaran kepada publik (umum). Jual beli melalui lelang, kesepakatan harga terbentuk pada saat lelang yaitu pada saat Pejabat Lelang untuk kepentingan penjual menunjuk penawar yang tertinggi dan mencapai harga limit sebagai pembeli lelang. Jadi jual beli lelang tidak murni terjadi antara pihak penjual dan pembeli, namun terdapat intervensi Pejabat Lelang berupa kewenangan Pejabat Lelang menunjuk pembeli lelang.

"Dengan demikian lelang termasuk perjanjian jual beli barang, karena terdapat syarat-syarat sahnya perjanjian. Kata sepakat dalam penjualan lelang terbentuk saat Pejabat Lelang untuk kepentingan penjual menunjuk penawar yang tertinggi dan mencapai harga limit sebagai pembeli lelang” (Zdzislaw Brodecki, 1992 ; 208).

"Lelang sebagai suatu perjanjian dalam pelaksanaannya tunduk pada klausula-klausula risalah lelang. Klausula risalah lelang ditetapkan secara sepihak oleh Kantor Lelang, yang mempunyai bargaining position yang lebih kuat dan pembeli lelang tidak mempunyai kemungkinan untuk mengubah klausul risalah lelang, sehingga risalah lelang merupakan perjanjian baku atau standar kontrak" (Mariam Darus Badrulzaman, $1991 ; 6)$.

\section{METODE PENELITIAN}

Metodologi yang penulis gunakan adalah metodologi hukum normatif. Penelitian normatif atau penelitian hukum kepustakaan adalah penelitian hukum dengan menggunakan data sekunder yaitu data yang diperoleh dari bahan-bahan pustaka. Dalam penelitian hukum normatif ini, penulis mengumpulkan data berupa data-data sekunder yang diperoleh dari buku-buku, Undang-Undang serta sumber kepustakaan lainnya.

\section{PERMASALAHAN}

Berdasarkan pemaparan yang telah dikemukakan dalam latar belakang diatas maka penulis menitikberatkan pada dua permasalahan yakni pertama, Bagaimanakah perlindungan hukum bagi pembeli yang beritikad baik melalui lelang eksekusi hak tanggungan? Kedua, Bagaimanakah kendala eksekusi objek lelang bagi pembeli lelang ?

\section{PEMBAHASAN}

\section{Perlindungan Hukum Bagi Pembeli Yang Beritikad Baik Melalui Lelang Eksekusi Hak Tanggungan}

Perlindungan hukum terhadap pembeli lelang memiliki makna bahwa adanya kepastian hukum atas hak pemenang lelang dari objek eksekusi hak tanggungan yang dibelinya baik secara yuridis maupun secara materiil melalui mekanisme lelang. Dalam proses lelang yang dilakukan akan menimbulkan akibat hukum yakni adanya peralihan hak objek lelang dari penjual kepada pembeli lelang. Hak Tanggungan timbul karena adanya suatu perjanjian, yakni adanya kesepakatan antara para pihak. Lelang merupakan penjualan secara umum yang dilakukan dihadapan pejabat lelang yang berwenang dan peralihan hak kepemilikan objek lelang dinyatakan dalam risalah lelang.

Dalam kasus eksekusi objek hak tanggungan, apabila pemilik sebelumnya tidak mau dengan suka rela untuk mengosongkan objek lelang hak tanggungan tersebut, upaya perlindungan hukum terhadap pembeli lelang yakni berarti bahwa adanya suatu kepastian hukum terhadap hak pemenang atau pembeli lelang untuk dapat menguasai atau mengeksekusi objek lelang yang telah 
dimilikinya secara yuridis maupun secara materiil. Perlindungan hukum terhadap pihak ketiga yang membeli hasil lelang dapat dikatakan masih terbilang minim. Hal tersebut sering terjadi yakni dalam Undang-Undang Nomor 4 tentang Hak Tanggungan Atas Tanah Beserta BendaBenda Yang Berkaitan Dengan Tanah lebih menekankan pada perlindungan hukum kreditur dari pada debitur ataupun pihak ketiga.

Bahkan penjual dan pejabat lelang cenderung menghindari kewajiban hukumnya untuk melindungi pihak ketiga sebagai pembeli lelang. Seperti pada salah satu prinsip yang ditegaskan oleh Mahkamah Agung terkait jual beli adalah "pembeli yang beritikad baik harus selalu dilindungi”. Konsekuensi dari adanya jual beli, dalam hal ini jual beli melalui lelang eksekusi Hak Tanggungan yakni jual beli yang dilakukan oleh pembeli yang beritikad baik dengan penjual harus dianggap sah. Bentuk perlindungan hukum pembeli lelang dalam eksekusi hak tanggungan dapat berupa perlindungan hukum secara preventif dan represif. Perlindungan hukum secara preventif bagi pembeli lelang hak tanggungan merupakan suatu bentuk perlindungan yang diberikan kepada pembeli atau pemenang lelang sebelum terjadinya suatu sengketa terkait dengan objek lelang.

Vendu Reglement memberikan perlindungan secara preventif terhadap pemenang atau pembeli lelang eksekusi hak tanggungan terkait peralihan hak objek lelang. Sebelum melaksanakan lelang, pejabat lelang telah melakukan analisis yuridis terhadap dokumen persyaratan lelang sehingga lelang dapat dilaksanakan sesuai dengan peraturan perundang-undangan yang berlaku. Selain perlindungan hukum secara preventif, pemenag atau pembeli lelang eksekusi hak tanggungan juga mendapatkan perlindugan hukum secara represif. Perlindungan represif menurut Hadjon adalah upaya untuk mendapatkan perlindungan hukum yang dilakukan melalui badan peradilan. "Perlindungan represif terhadap pembeli lelang eksekusi hak tanggungan terdapat dalam Pasal 200 HIR (Herzein Inlandsch Reglement) dan Pasal 218 ayat (2) RBG (Rechtreglement voor de Buitengewesten)"

Dalam tatanan praktik seharusnya perlindungan hukum pembeli lelang dalam eksekusi objek hak tanggungan, apabila terjadi objek lelang tersebut tidak dapat dikuasai oleh pihak ketiga pembeli lelang dikarenakan pihak tereksekusi tidak mau dengan sukarela untuk mengosongkan objek lelang tersebut harus sudah diatur dalam peraturan perundang-undangan. Apabila dianalisa berdasarkan pemikiran Teori "Law as tool of social engineering" yang dipelopori oleh Roscoe Pound atau hukum sebagai alat pembaruan masyarakat mulanya dikemukakan oleh Roscoe Pound dan merupakan inti dari pemikiran aliran "Pragmatic Legal Realism” (Lili Rasjidi, 2002 ; 73).

"Konsep tersebut dimodifikasi menjadi hukum sebagai sarana pembangunan oleh Mochtar Kusumaatmaja (Mochtar Kusumaatmaja, 2002 ; 5). Jika teori tersebut diterapkan dalam pembaruan peraturan perundangundangan terkait dengan lelang, maka diharapkan peraturan perundangundangan lelang ke depan akan berfungsi sebagai sarana (pengatur) arah perkembangan lelang dengan konsep hukum yang lebih memberikan perlindungan hukum berupa kepastian hak pembeli lelang atas barang yang dibelinya dan keadilan terhadap pembeli lelang, proses lelang yang rasional sehingga transparan dan dapat dipertangungjawabkan serta : mengembangkan lelang dengan peran pemerintah".

\section{Kendala Eksekusi Objek Lelang Bagi Pembeli Lelang}


Salah satu ciri dari Hak Tanggungan adalah mudah dan pasti dalam pelaksanaan eksekusinya apabila dikemudian hari debitor wanprestasi. "Secara teoritis jika dilihat berdasarkan teori positifisme atau hukum positif yang saat ini berlaku yakni dalam UndangUndang Nomor 4 Tahun 1996 Tentang Hak Tanggungan Atas Tanah Beserta BendaBenda Yang Berkaitan Dengan Tanah sudah mengatur secara tegas dan terperinci dalam pelaksanaan eksekusi Hak Tanggungan, namun dalam praktek masih banyak hambatan- hambatan yang dapat menghambat jalannya eksekusi tersebut. Meskipun aturan tersebut udah secara tegas termuat dalam Undang-Undang Nomor 4 Tahun 1996 Tentang Hak Tanggungan Atas Tanah Beserta BendaBenda Yang Berkaitan Dengan Tanah, tapi jika dilihat berdasarkan teori kepastian hukum, maka bisa dikatakan belum sepenuhnya menjamin proses eksekusi objek Hak Tanggungan tersebut dikarenakan adanya kendala-kendala yang menghambat proses eksekusi tersebut".

Menurut pendapat R. Setiawan keadaan memaksa (Overmacht) adalah suatu keadaan yang terjadi setelah dibuatnya persetujuan, yang menghalangi debitur untuk memenuhi prestasinya, di mana debitur tidak dapat dipersalahkan dan tidak harus menanggung resiko serta tidak dapat menduga pada waktu persetujuan dibuat. "Kesemuanya itu sebelum debitur lalai untuk memenuhi prestasinya pada saat timbulnya keadaan tersebut. Definisi tersebut perlu diuraikan lebih lanjut sebagai berikut:

1. Keadaan yang menimbulkan keadaan memaksa tersebut harus terjadi setelah dibuatnya persetujuan.

2. Keadaan yang menghalangi pemenuhan prestasi harus mengenai prestasinya sendiri.

3. Debitur tidak dapat menyerahkan barangnya karena dicuri, tidak dapat dinyatakan bersalah, jika ia telah berusaha sebaik-baiknya untuk menyimpan barang tersebut.

4. Debitur tidak harus menanggung resiko berarti debitur baik berdasarkan undang-undang, persetujuan maupun pandangan yang berlaku dalam masyarakat, tidak harus menanggung resiko.

5. Debitur tidak dapat menduga akan terjadinya peristiwa yang menghalangi pemenuhan prestasi pada waktu perikatan dibuat" (R. Setiawan, 1987 ; 28).

Dalam suatu pelaksanaan lelang kewajiban dari pembeli adalah melakukan pembayaran terhadap harga lelang.

Selain kendala terebut, dapat kita temui juga kendala dalam hambatan non yuridis yakni :

1. Adanya kendala dari pihak-pihak debitur yang mana dengan sengaja untuk menghambat jalannya proses eksekusi objek Hak Tanggungan tersebut dengan berbagai macam cara yaitu, dengan sengaja memblokir jalan untuk menuju lokasi objek Hak Tanggungan tersebut, menghalangi para aparatur keamanan dengan membuat kegaduhan.

2. Kurang adanya pengetahuan serta pemahaman dari para masyarakat terkait hukum, sehingga mudah untuk dipengaruhi serta di provokasi oleh pihak debitur dan pihak-pihak yang tidak bertanggung jawab.

\section{PENUTUP \\ Kesimpulan}

Peraturan pelaksanaan lelang yang ada selama ini belum memberikan perlindungan hukum sepenuhnya kepada pemenang/pembeli lelang, dalam artian bahwa Vendu Reglement yang menjadi dasar hukum utama lelang di Indonesia serta Peraturan Menteri Keuangan Nomor 27/PMK/2016 Tentang Petunjuk Pelaksanaan Lelang belum ditemukan adanya perlindungan hukum kepada 
pembeli lelang eksekusi Hak Tanggungan. Risalah lelang sendiri pun tidak memberikan perlindungan hukum kepada pembeli lelang atas penguasaan objek lelang tersebut. Dalam hal ini HIR (Herzein Inlandsch Reglement) memberikan perlindungan hukum secara represif yang menegasakan perintah untuk pengosongan objek lelang dapat meminta bantuan kepada Pengadilan Negeri, dan apabila terjadi kesulitan dalam pengosongan objek lelang maka pihak ketiga yang merasa dirugikan dapat mengajukan upaya hukum.

\section{Saran}

Penulis memberikan suatu pandangan untuk saran atas kesimpulan yang ada bahwa hambatan-hambatan dalam proses eksekusi Hak Tanggungan meliputi hambatan yuridis dan hambatan non yuridis, atas dasar hambatanhambatan tersebut mengakibatkan proses eksekusi Hak Tanggungan tidak dapat dilaksanakan dengan baik dan lancar. Upaya penyelesaian hambatan yuridis tersebut dapat dilakukan menurut ketentuan hukum yang berlaku, sedangkan untuk hambatan non yuridis upaya penyelesaian yang dapat dilakukan yakni dengan melakukan koordinasi antara pihak-pihak terkait serta menambah aparat keamanan dan melakukan sosialisasi penyuluhan hukum pada masyarakat.
DAFTAR PUSTAKA

Bachtiar Sibarani, Masalah Hukum

Privatisasi Lelang, Jakarta, 2006

Lili Rasjidi, Pengantar Filsafat

Hukum, Bandung, Mandar

Maju, 2002

Mariam Darus Badrulzaman, Perjanjian Baku (Standar)

Perkembangannya di

Indonesia, Bandung,

Alumni,1991

Mochtar Kusumaatmaja, Konsep-

Konsep Hukum Dalam

Pembangunan, Bandung,

Alumni, 2002

R. Setiawan, Pokok-Pokok Hukum

Perikatan, Bandung, Binacipta, 1987

Remy Sjahdeini, Hak Tanggungan,

Asas-Asas, Ketentuan-

Ketentuan Pokok dan Masalah

yang Dihadapi Oleh

Perbankan, Bandung Alumni, 1999

Urip Santoso, Pendaftaran dan Peralihan Hak Atas Tanah, Jakarta, Kencana, 2010

Vijay Krisna, Auction Theory, Florida

USA, Academic Press, 2002

Zdzislaw Brodecki, Polish Businees

Law, (Nederlands:Kluwer Law

Internasional

1992 
